\title{
Global Uncertainty and Monetary Policy Effectiveness in Pakistan
}

\author{
Inayat U. Mangla* and Kalim Hyder**
}

\begin{abstract}
This article investigates monetary policy effectiveness in Pakistan in the presence of external uncertainties stemming from the economic growth of developed economies and international oil price movements. We estimate a structural VAR model to gauge the impact of international oil prices and global demand on key macroeconomic variables in Pakistan. Our findings suggest that monetary policy remains an effective tool for controlling inflation. An increase in oil prices (supply shock) leads to higher real policy rates, real exchange rate depreciation, an economic growth slowdown and rising inflation. A global demand surge leads to higher real policy rates, real exchange rate appreciation, economic growth and rising inflation. Real policy rates adjust upward in response to inflation and real exchange rate shocks. The real exchange rate depreciates if inflation increases. This indicates that the monetary authorities in Pakistan are generally able to stabilize consumer prices and real exchange rates in the economy.
\end{abstract}

Keywords: Monetary policy, real exchange rate, inflation, oil prices, Pakistan.

JEL classification: E22, E47, E52, E58.

\section{Introduction}

There is only one difference between a bad economist and a good one: the bad economist confines himself to the visible effect; the good economist takes into account both the effect that can be seen and those effects that must be foreseen. (Claude-Frédéric Bastiat, 19th century French economist)

\footnotetext{
* Professor of Finance, Lahore School of Economics; Professor of Finance Emeritus, Department of Finance and Commercial Law, Haworth College of Business, Western Michigan University, Kalamazoo, MI, USA.

** Monetary Policy Department, State Bank of Pakistan, Karachi, Pakistan.
} 
The objective of this paper is to analyze the global spillover effects that different central banks' monetary policies can have on emerging economies such as Pakistan. Former governor of the Reserve Bank of India, Raghuram Rajan, suggests categorizing such policies as green, red or orange. ${ }^{1}$ Green denotes policies with very little spillover. Red policies are those that should be avoided: these include unconventional monetary policies that have a small positive effect on exports to emerging economies, enable a feeble recovery in the source country and lead to large capital outflows and asset price bubbles in emerging markets. Orange, therefore, denotes those policies that should be used temporarily and with care.

In investigating the impact of global uncertainty, it is important to ask where macroeconomics stands. For over four decades, macroeconomics has moved in reverse, with macroeconomic theorists now inclined to dismiss such simple assertions as "tight monetary policy can cause a recession" (Romer, in press). One way of testing the claim that monetary policy does not matter is to consider the case of the Volcker deflation. The best indicator of monetary policy is the real federal funds rate or real short-term rate (the nominal rate minus the inflation rate), which was higher during Paul Volcker's term as chairman of the Fed than at any other time post-World War II. Romer and Romer (1989) recount the internal discussion at the Fed leading up to this abrupt change. Fed officials expected the change to cause a "prompt increase in the Fed funds rate" that would "dampen inflationary forces in the economy". Thus, US unemployment increased from 7.2 to 10.8 percent. The US data suggests a simple causal explanation for this that is consistent with what Fed insiders anticipated:

- High real interest rates decreased output and increased unemployment.

- The rate of inflation fell, either because the combination of higher unemployment and a larger output gap caused it to fall or because the Fed's actions changed expectations.

If the Fed can cause a 500-basis point change in nominal interest rates above the prevailing inflation rate, it is unreasonable to wonder if monetary policy is important. The only sense in which monetary policy is not important is if we argue that, despite what people at the Fed thought, they

1 See http://economictimes.indiatimes.com/news/economy/policy/rbi-governorraghuram-rajan-for-guidelines-by-nations-on-monetary-policybehaviour/articleshow/51587642.cms 
did not change the Fed funds rate. If history tends to repeat itself, then the US monetary policy experience offers insights for other central banks that wish to make their policies more effective in a global economy. The prevalence of recessionary tendencies in the developed world is a major concern, as monetary policy is constrained by zero-bound interest rates. Macro-prudential regulation and the adoption of quantitative easing (QE) are considered complements to (in the US and UK) or substitutes for (in Japan and the EU) the interest rate setting policy.

Let us keep in mind that the trend toward lower interest rates dates back well before the global crisis of 2008/09. Globally, the decline in longterm interest rates falls into three broad categories: (i) an increase in the propensity to save, (ii) a fall in the propensity to invest and (iii) shifts in the demand and supply of different types of assets. The evidence supports the idea that shifts in saving associated with demographics and Chinese financial integration were likely dominant factors, particularly in the decade or so before the global financial crisis.

There are several ways in which a Fed rate hike hits the global economy. One interest rate hike in 2015 is a tweak. A second in mid-March 2017 and a third in June 2017 denotes the process toward normalization. There are five key trends to watch for: (i) marking the end of super-cheap money, (ii) preparing for inflation, (iii) expecting the saving rate to rise, (iv) expecting heavy budgetary pressure on governments and (v) expecting a trade war between the US and Europe. Nonzero rates have been the most important factor in the global economy for a decade: they have changed the way assets are priced, dictated saving rates and allowed governments to borrow.

Against this background, we explore the impact of global monetary developments on Pakistan's economy. The declining demand for its exports stems primarily from recessions in the developed world and the uncompetitive nature of these exports, given the lack of technological upgrading. This has created uncertainties with respect to Pakistan's economic revival. While capital flows to emerging economies due to significant Quantitative Easting (QE) in the developed world may have positive effects, a sudden reversal of these flows - as policy changes taper off - can also have negative repercussions. The ineffectiveness of monetary policy can also be considered a challenge.

We assess and quantify the effectiveness of monetary policy in the presence of these uncertainties, which stem from declining exports, falling 
remittances and volatile capital flows. In addition, the effectiveness of monetary policy relies on the extent of policy coordination between fiscal and monetary policy. The relative dominance of either can create an imbalance and hinder the effectiveness of both policies. Therefore, balanced, coordinated policy efforts are imperative if monetary policy is to be effective.

We use recursive structural vector autoregression (SVAR) to measure the impact of global uncertainty on the effectiveness of monetary policy. A recursive model is useful because small open economies have no effect on the global economy, while on the other hand global development can affect small economies. Our findings indicate that global demand and international commodity prices have a significant impact on Pakistan's economy. Further, the State Bank of Pakistan plays an effective role in controlling inflation and managing the exchange rate.

\section{Literature Review}

Discretionary monetary policies become ineffective when policymakers make inconsistent policy decisions after optimizing the social objective function (Kydland \& Prescott, 1977; Calvo, 1978; Barro \& Gordon, 1983). The social loss function assigns weights to the deviations of output and inflation from their optimal levels. Thus, dynamic inconsistency produces higher inflation than is socially optimal (Rogoff, 1985). This arises when the rational public uses the expected path of a given variable to make current economic decisions.

This issue of inconsistency can be resolved by setting rule-based policies with regard to the future path of a variable (Kydland \& Prescott, 1977). Paul Volcker's disinflation policy of 1979-82 demonstrates that firm commitment on the central bank's part to controlling inflation has effective results. The success of Volcker's experiment and its solid theoretical rationale shows that the credibility of the policymaker is a core factor in the effectiveness of monetary policy. Following these developments, central banks were given greater independence. Most of them adopted inflationtargeting regimes with a firm commitment to reducing inflation. Governments aiming to increase social welfare indicated their commitment to price stability by giving the central bank the mandate and credibility needed to manage inflation expectations.

Bernanke (2007) and Rusticelli, Turner and Cavalleri (2015) show that economic developments, the conduct of monetary policy and the credibility of the central bank play an important role in anchoring inflation 
expectations. Beechey, Johannsen and Levin (2011) find that long-run inflation expectations are reasonably well-anchored in the EU and US. Weise (1999) indicates that the positive and negative shocks of monetary policy have symmetric effects. These findings show that monetary policy has been successful in reducing inflation uncertainties in developed countries. The stylized facts reaffirm that monetary policy plays an effective role in controlling inflation.

However, after the financial crisis, monetary policy was deemed ineffective in helping economies out of a recession. Blanchard, Dell'Ariccia and Mauro (2010) argue that low inflation limits the scope of monetary policy in a recession. This gives more credence to the use of fiscal policy over monetary policy. Tenreyro and Thwaites (2016) find that monetary policy in the US has been more effective during an expansion than a recession. For instance, the US initiated QE in November 2008, signaled in May 2013 that it was going to stop these measures and then terminated the QE in October 2014.

Figure 1 illustrates how developed economies took steps to recover from the recession by drastically reducing their policy rates. However, these efforts did not pay off, as growth and inflation remained below target. The temporary recovery that followed the financial crisis can be attributed to bailout packages and policy actions. The inflation and growth targets were not achieved until 2010, after which real economic growth stagnated even as inflation fell. The prevalence of recessionary tendencies in the developed world is, therefore, a key concern for policymakers (Figures 1 and 2).

\section{Figure 1: Average policy rates of major economies}

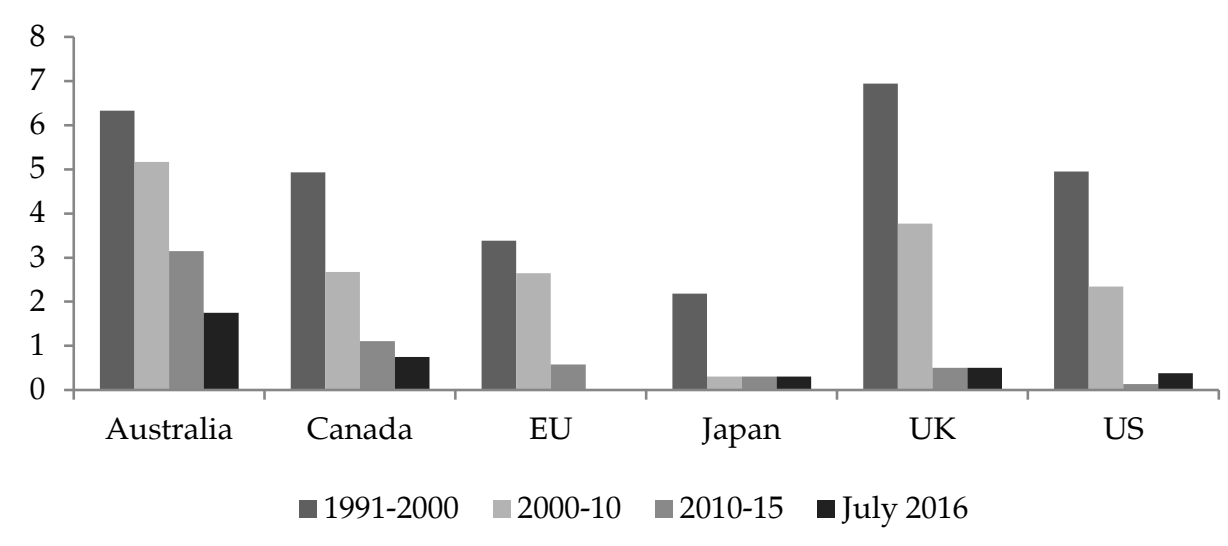

Source: Average Policy Rates of Developed Economies 
Figure 2: Real economic growth (year-on-year)

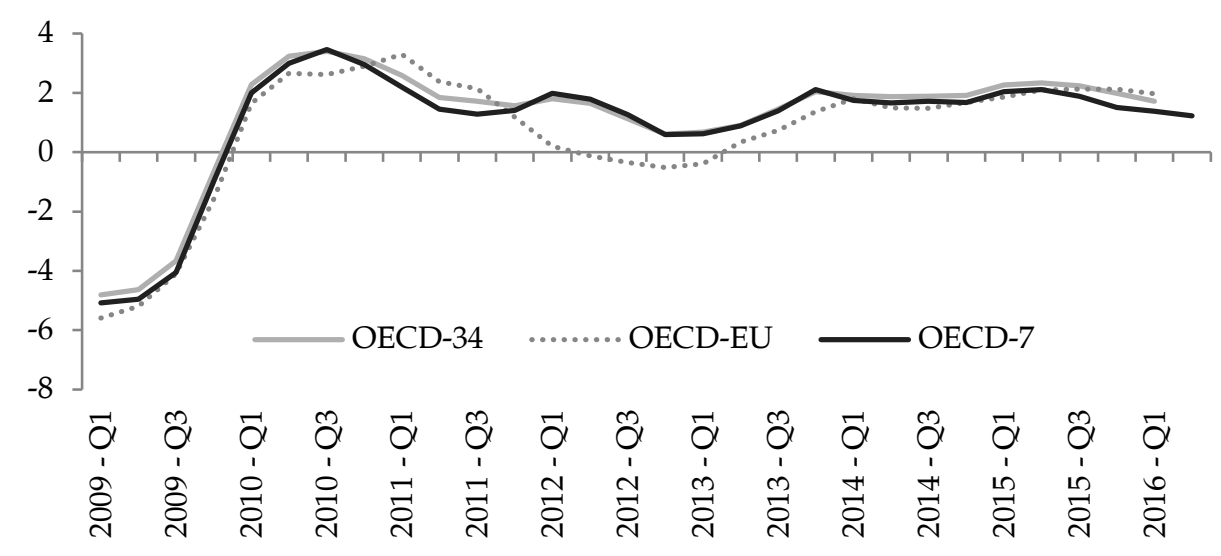

Source: Real Economic growth of Developed Economies

In attempting to restore growth and achieve their inflation targets, central banks deployed one target (inflation) and one tool (short-term interest rates) and reduced policy rates mechanically. However, these large doses of monetary expansionary not only failed to improve the situation, but also left central banks with zero-bound policy rates (Figure 3). Given the uncertain pace at which such steps were likely to pass through, central banks adopted the more unconventional monetary policy of large-scale asset purchase (QE). However, the data for the first two quarters of 2016 reflects the same problem: low growth and below-target inflation.

\section{Figure 3: Inflation (year-on-year)}

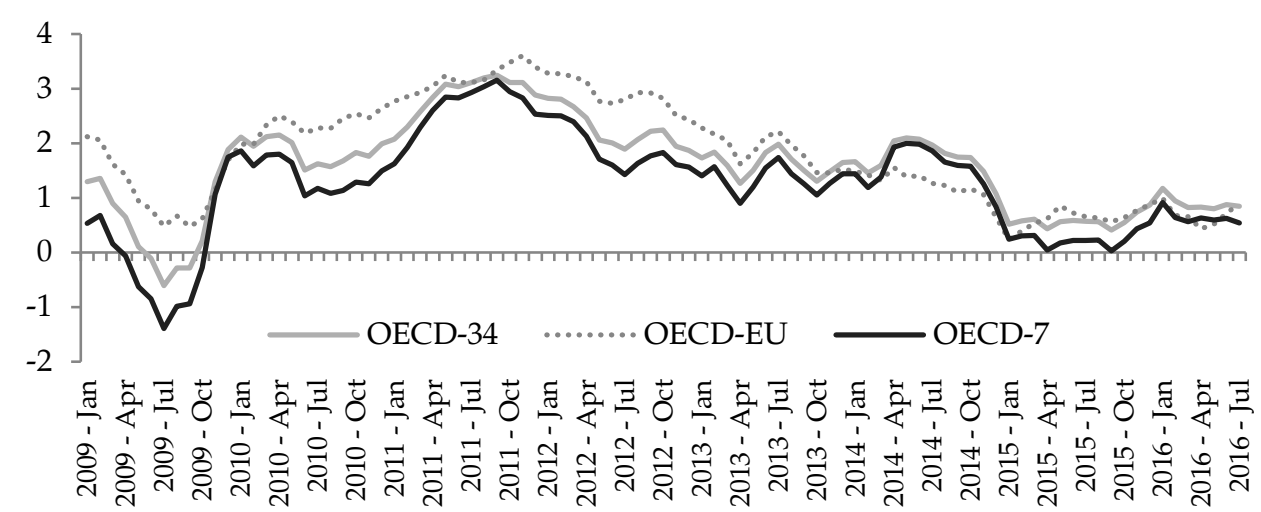

Source: Inflation of Developed Economies 
Such developments have had both positive and negative implications for connected emerging economies. Georgiadis (2016) and Bowman, Londono and Sapriza (2015) examine the impact of QE on domestic and cross-border economies. Ishi, Stone and Yehoue (2009) indicate that limited financial stress, external vulnerabilities and the smaller scope for quasi-fiscal activities may restrict the role of unconventional policies in emerging economies. This implies that when a global recession passes through to emerging economies in the shape of lower export demand, their limited ability to tackle this creates greater uncertainties.

On the other hand, emerging economies enjoy the benefits of excess currency supplies in developed countries and historically low interest rates. The main spillovers are stable currencies, large capital inflows and the availability of low-cost debt. Fratzscher, Lo Duca and Straub (2017) show that capital flows in emerging economies improve due to QE in advanced economies. Highly indebted economies gain some breathing space in their interest rate payments due to lower interest rates. Aizenman, Binici and Hutchison (2014), however, point out that these inflows are due to news effects and may be reversed at any time, with an adverse impact on emerging economies. To gauge the impact of these global developments on Pakistan's economy, Table 1 provides some statistics on foreign direct investment (FDI) for selected Asian countries.

Table 1: FDI inflows to selected countries (US\$ mil)

\begin{tabular}{rrrrrrrr}
\hline Year & Bangladesh & India & Indonesia & Malaysia & Pakistan & Philippines & Thailand \\
\hline 2000 & 280 & 3,584 & $-4,550$ & 3,788 & 308 & 1,487 & 3,366 \\
2001 & 79 & 5,128 & $-2,977$ & 554 & 378 & 760 & 5,067 \\
2002 & 52 & 5,209 & 145 & 3,193 & 826 & 1,769 & 3,342 \\
2003 & 268 & 3,682 & -597 & 3,219 & 534 & 492 & 5,232 \\
2004 & 449 & 5,429 & 1,896 & 4,376 & 1,118 & 592 & 5,860 \\
2005 & 761 & 7,269 & 8,336 & 3,925 & 2,201 & 1,664 & 8,223 \\
2006 & 457 & 20,029 & 4,914 & 7,691 & 4,273 & 2,707 & 8,926 \\
2007 & 651 & 25,228 & 6,929 & 9,071 & 5,590 & 2,919 & 8,621 \\
2008 & 1,328 & 43,406 & 9,319 & 7,573 & 5,438 & 1,340 & 8,566 \\
2009 & 901 & 35,581 & 4,877 & 115 & 2,338 & 2,065 & 6,427 \\
2010 & 1,232 & 27,397 & 15,292 & 10,886 & 2,022 & 1,070 & 14,715 \\
2011 & 1,265 & 36,499 & 20,565 & 15,119 & 1,326 & 2,007 & 2,468 \\
2012 & 1,584 & 23,996 & 21,201 & 8,896 & 859 & 3,215 & 12,895 \\
2013 & 2,603 & 28,153 & 23,282 & 11,296 & 1,333 & 3,737 & 15,822 \\
2014 & 2,539 & 33,871 & 26,277 & 10,619 & 1,867 & 5,740 & 3,719 \\
2015 & 3,380 & N/A & N/A & 10,963 & 979 & 5,724 & 7,062 \\
\hline
\end{tabular}

Source: Foreign Direct Investment Inflows to Selected Countries (Mil. US\$) 
Generally, declining external demand is due to recessions in developed countries, which creates uncertainties for emerging economies. Pakistan's economy has been unfortunate in attracting capital during the QE period. FDI inflows to Pakistan have been low since the 1980s: on average, 0.58 percent of GDP from 1976 to 2000. Under privatization, these flows increased to 2 percent of GDP during the 2000s, but have fallen to 0.56 percent over the last six years.

Table 1 shows that Bangladesh, India, Indonesia, Malaysia, the Philippines and Thailand received larger inflows than Pakistan. This may have been due to the country's uncertain security situation and inadequate efforts to attract FDI. These statistics improved in 2016 due to CPEC inflows. Pakistan's case is different when it comes to QE spillovers. Although it mobilized foreign debt by issuing bonds, these inflows were used to stabilize the currency. The fiscal space created by cheaper debt helped reduce the budget deficit from 8.8 percent in FY2012 to 4.6 percent in FY2016. While Pakistan did not benefit as much from QE spillovers as other emerging economies, it was still hit as hard by the fall in global demand for exports (Figure 4).

Figure 4: Trends in world exports and Pakistan's exports

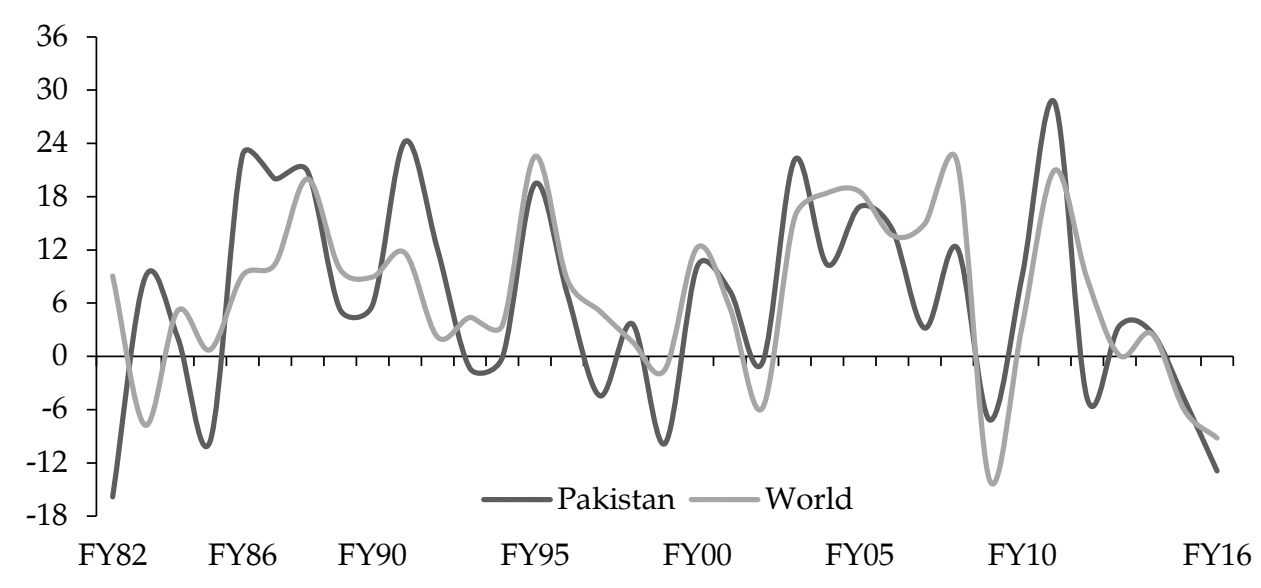

Source: Trend of World and Pakistan's Exports

Since the EU, the US and the UK are Pakistan's most important export destinations, the slowdown in these economies has had a severe impact on its export performance. This is evident from the negative growth in exports in recent years. The exports-to-GDP ratio was 11 percent in FY2012 and declined to 8.9 and 7.7 percent, respectively, in FY2015 and 
FY2016. Falling commodity prices and diminishing demand were both responsible for this decline in exports.

\section{Theoretical and Methodological Framework}

This paper analyzes the impact of external shocks and monetary policy changes on inflation and economic growth in Pakistan. The external shocks we look at are international crude oil prices and foreign demand. The effectiveness of monetary policy is gauged by the effect of real policy rates on inflation in consumer prices.

Using a reduced-form SVAR (see Ahmed, 2003; Ahmed, Ara \& Hyder, 2006) applied to quarterly data, we estimate the impact of unanticipated external shocks on the policy variable, based on impulse responses. Our findings could help policymakers better understand the impact of global changes on Pakistan's economy and thus design a more effective monetary policy.

Although the variables in question are stationary, there is the possibility of a long-term relationship among these variables. Ignoring this cointegrating relationship could lead to a misspecification error. To prove the robustness of the estimates, the same SVAR is estimated using the local projection method (see Jordà, 2005), the advantage being that its results are not sensitive to misspecification errors. There may also be structural changes in the data that could lead to invalid estimates. We resolve this by using fixed and flexible windows for the subsample.

\subsection{Structural VAR}

The SVAR equation without the intercept term is as follows:

$$
A Y_{t}=\sum_{i=1}^{J} B_{i} Y_{t-i}+\epsilon_{t} \equiv B(L) X_{t-i}+\epsilon_{t}
$$

$Y$ is the vector of stationary variables. $A$ represents the contemporaneous interactions between the endogenous variables and $B$ represents the lag effects. $\epsilon$ is the vector of i.i.d. structural disturbances with the covariance matrix G. As a small open economy, Pakistan can be affected by external variables, but cannot influence the external environment. This implies that there is no likelihood of reverse causality. Therefore, the $Y$ vector is decomposed into external and domestic variables: 


$$
Y=\left[\frac{Y_{1}}{Y_{2}}\right]=\left(\begin{array}{c}
O I L \\
\frac{U I P}{T B R} \\
E X R \\
G r t \\
\text { Inf }
\end{array}\right) \text { and } \epsilon \equiv\left[\frac{\mu}{v}\right]=\left[\begin{array}{c} 
\\
\mu_{1} \\
\frac{\mu_{2}}{v_{1}} \\
v_{2} \\
v_{3} \\
v_{4} \\
v_{5}
\end{array}\right]
$$

The external variable $Y_{1}$ denotes the growth in international crude oil prices (OIL) and in US industrial production (UIP). The policy and domestic variables denoted by $Y_{2}$ include the real treasury bill rate (TBR), the real exchange rate (EXR), domestic output growth (GRT) and domestic inflation (INF). The vector $\mu$ includes external shocks (OIL and UIP) and the vector $v$ denotes domestic shocks to the real interest rate, exchange rate and domestic price level after accounting for the impact of external shocks on these variables.

The fundamental economic disturbances in the vector $\mu$ are i.i.d., which implies that a diagonal covariance matrix cannot fully identify structural models such as equation (1). To analyze the effect of various shocks, further identification restrictions are needed. We place coefficient restrictions on the A and B matrices as shown below:

$$
\begin{aligned}
& A \equiv\left(\begin{array}{l}
\left.A_{11} \mid \begin{array}{l}
A_{12} \\
A_{21} \\
A_{22}
\end{array}\right)=\left(\begin{array}{ccc|ccc}
1 & 0 & 0 & 0 & 0 & 0 \\
* & 1 & 0 & 0 & 0 & 0 \\
* & * & 1 & 0 & 0 & 0 \\
* & * & * & 1 & 0 & 0 \\
* & * & * & * & 1 & 0 \\
* & * & * & * & * & 1
\end{array}\right) \\
B(L) \equiv\left(\begin{array}{l}
B(L)_{11} \\
B(L)_{21} \mid
\end{array} \mid B(L)_{22}\right.
\end{array}\right)=\left(\begin{array}{ccc|ccc}
* & * & 0 & 0 & 0 & 0 \\
* & * & 0 & 0 & 0 & 0 \\
* & * & * 1 & 0 & 0 & 0 \\
* * & * & * & * & 0 & 0 \\
* & * & * & * & * & 0 \\
* & * & * & * & * & *
\end{array}\right)
\end{aligned}
$$

An asterisk denotes that the coefficient is unrestricted. Given that Pakistan is considered a small open economy, the external variables are assumed to be exogenously given. This is reflected in $A_{12}$ and $B(L)_{12}$ being null matrices. Note that this makes the system block recursive.

Regarding the external variables, we assume that the contemporaneous direction of causality is from oil prices to foreign output, which means that $A_{11}$ is lower-triangular. Since monetary policy decisions are based on information about global developments, real policy rates will be influenced by the latter. Monetary policy decisions have no impact on 
global developments. This is consistent with the causal ordering above and implies that $B(L)_{11}=0$.

Regarding the domestic variables, we assume the contemporaneous causal ordering is from the real exchange rate to domestic output to the domestic price level, which implies a lower-triangular $A_{22}$. Since prices are usually sticky in the short run, putting the price level last seems appropriate. What is more controversial is the direction of contemporaneous causality between the real exchange rate and output. Certainly, changes in the exchange rate policy, which could be one source of domestically driven shocks to the real exchange rate, can affect output. However, some domestic shocks, such as supply shocks or fiscal shocks, can also affect both output and the real exchange rate. Since asset markets typically react faster, the exchange rate is likely to respond to these shocks more quickly than output. Hence, we put the real exchange rate ahead of output in the contemporaneous causal ordering - feedback from output changes to real exchange rate changes with a lag is, of course, allowed.

The SVAR given in equation (1) cannot be directly estimated, but must be retrieved from the reduced form of the system. The relationship between the SVAR and its reduced form becomes evident when we premultiply equation (1) by $A^{-1}$ to yield

$Y_{t}=A^{-1} B(L) Y_{t-1}+A^{-1} \epsilon_{t} \equiv \mathrm{T}(L) Y_{t-1}+v_{t}$

This is the reduced form of the system that can be estimated using OLS. The relationship between the matrix of the structural disturbances and the reduced form can be written as:

$E\left(v_{t} v_{t}^{\prime}\right) \equiv \Omega=E\left[\left(A^{-1} \mu_{t}\right)\left(A^{-1} \mu_{t}\right)^{\prime}\right]=E\left(A^{-1} \mu_{t} \mu_{t}^{\prime} A^{-1^{\prime}}\right)=A^{-1} D A^{-1^{\prime}}$

$\mathrm{E}$ is the expectation operator. Identifying the structural model from the estimated reduced form of equation (5) thus involves finding an A matrix such that $\Omega=A^{-1} D A^{-1^{\prime}}$ where $\mathrm{D}$ is diagonal. While this process does not yield a unique $\mathrm{A}$, the restriction mentioned above provides a lowertriangular $\mathrm{A}$ that is unique.

\subsection{Local Projections}

The presence of a unit root in the variables raises the question of whether to estimate the SVAR in levels (with variables in nonstationary form), first-differenced (with variables in stationary form) or in a VAR that imposes 
cointegration (an error correction model). The considerable body of literature on this issue tends to suggest that, even if the variables have unit roots, it is still desirable to estimate an SVAR in levels. Sims, Stock and Watson (1990) show that the estimated coefficients of a VAR are consistent and the asymptotic distribution of individual estimated parameters is standard (i.e., the asymptotic normal distribution applies) when variables have unit roots and there are some variables that form a cointegrating relationship.

We do not impose possible unit roots and cointegration in our VAR. We justify the specification in levels based on the Monte Carlo results of Lin and Tsay (1996). The problem is that cointegration tests often indicate too many or, occasionally, too few, cointegrating vectors and, therefore, lead to misspecification. On the other hand, a VAR specified in first differences assumes that the variables are not cointegrated because no error correction terms are included. If there is cointegration, then such a model in first differences is mis-specified.

The impulse response functions of the VAR model in levels are also consistent estimators of their true impulse response functions in the short and medium run, but not in the longer run. As shown by Phillips (1998), in the longer run the standard impulse responses do not converge to their true values with a probability of 1 when unit roots or near-unit roots are present and the lead time of the impulse response function is a fixed fraction of the sample size. For this reason, we use an alternative method to estimate the impulse responses, based on local linear projections as suggested by Jordà (2005), which are robust to this problem.

\section{Data and Unit Root Tests}

The real policy rate is considered a tool of monetary policy. In this case, we examine its impact on the exchange rate, inflation and growth. The empirical model uses average international crude oil prices of Saudi Arabian light and US industrial production as an indicator of global demand or real economic activity. The bilateral exchange rate (Pakistan rupees in terms of US dollars) is taken as the real exchange rate, after deflating it by the consumer price index.

The impact variables include inflation in consumer prices and real economic growth (represented by the growth in industrial production). Barring the real interest rate, we calculate the growth of the other variables, using data from various issues of the Pakistan Economic Survey and the State Bank of Pakistan's annual reports and statistical bulletins. While the level of 
these variables is nonstationary, their growth is stationary. The real interest rate is stationary at level (Table 2). We use the short-term treasury bill rate (TBR) instead of the discount rate. The TBR is the continuous form of the discount rate (the discrete monetary policy tool). It changes instantly with a change in the discount rate and also captures changes in the money market.

Table 2: Unit root test results

\begin{tabular}{lcc}
\hline \multicolumn{1}{c}{ Variable } & ADF & DF-GLS \\
\hline Growth in international oil prices & $-13.32^{*}$ & $-4.31^{*}$ \\
US industrial production index & $-10.95^{*}$ & $-4.021^{*}$ \\
Real TB rate & $-2.50^{*}$ & $-2.60^{*}$ \\
Exchange rate & $-16.08^{*}$ & $-15.22^{*}$ \\
CPI inflation & $-6.70^{*}$ & $-3.87^{*}$ \\
Industrial production, Pakistan & $-12.39^{*}$ & $-8.70^{*}$ \\
\hline
\end{tabular}

Note: ${ }^{*}=$ significant at $1 \%$ level.

\section{Empirical Results}

We estimate the block recursive reduced-form SVAR for Pakistan, using monthly data for January 1991 to October 2016. The optimal lag length is chosen based on the AIC. The short-run coefficients are restricted to zero in case of insignificance, which helps save the degrees of freedom and improves the identification. After estimating the SVAR given in equation (5), the structural disturbances are used to carry out the impulse response and variance decomposition analyses (see Figures A1 to A5 in the Appendix). An investigation of the residuals indicates that oil prices and the exchange rate are relatively volatile.

\subsection{Impulse Response Analysis}

Impulse response functions capture a variable's response to an unanticipated shock to any of the external, policy or domestic variables. The impulse responses are derived from the SVAR, which is estimated using simple OLS and local projections. In both cases, the variable's impulse responses are found to move closely together, thus confirming the robustness of the results. The consistent estimates from the flexible and fixed windows estimation of the SVAR also indicate that these results are robust and there are no visible structural shifts in the data.

An unanticipated shock to oil prices will reduce the real policy rate due to increasing prices. The real policy rate remains low during the first 12 months and then starts to increase, indicating that it adjusts upward in 
response to the supply shock. Oil price shocks are regulated by the fiscal authorities, which administer energy prices in Pakistan. This gives the central bank enough time to respond to a shock, although Bernanke (2007) argues that the immediate impact of oil price shocks is due to the upward adjustment of inflation expectations. The central bank manages these expectations by gradually increasing the policy rate. The standard error bands confirm that oil price shocks have a statistically significant impact on the real policy rate. A shock to the US growth variable initially reduces the real policy rate during the first two months, although it increases later. This result is not statistically significant.

The results indicate that the monetary authorities are vigilant in the case of the exchange rate. An unanticipated depreciation shock leads to a statistically significant increase in the real interest rate. This occurred during June to September 1993, when the Pakistan rupee fell by PKR3 to the US dollar and the discount rate was increased by 200 basis points. Similar policy responses were witnessed in September 1995, September 1996, August 2000, FY2008 and August 2013. The real policy rate does not change much in response to an increase in productivity. An output shock does not have a statistically significant impact on the real rate. However, there is a slight increase in the real policy rate due to consumer price shocks. The magnitude of the upward adjustment in the policy rate is observed after 12 months.

While the response of the real exchange rate to an oil price shock is smaller in magnitude, there is a slight currency depreciation that adjusts in a couple of months. US productivity shocks have no significant impact on the real exchange rate. An increase in the real policy rate causes some depreciation in the real exchange rate in the first month, but significant appreciation in the second month and thereafter. Improvements in domestic productivity, indicated by shocks to real domestic industrial production, lead to a currency appreciation. An unanticipated increase in inflation causes the real value of currency to depreciate.

An unanticipated shock to oil prices is a contractionary supply shock according to our results, and reduces output in the second month. An improvement in US growth increases productivity in Pakistan - this may be due to an increase in the demand for exports. Real policy rates have no significant impact on economic growth. Depreciations are expansionary in the first two months and become contractionary later. This clearly implies that efforts to boost exports using depreciation are a short-term solution. Inflation also reduces economic growth. 
An oil price shock and demand surge in the US increases inflation in Pakistan. The effectiveness of monetary policy is evident from the response of inflation to an unanticipated shock to the policy rate. Overall, monetary policy is an effective means of controlling inflation. Depreciations are inflationary because any unanticipated shock in the real exchange rate increases inflation significantly in the second month. However, there is a slight fall in inflation due to a depreciation shock in the first horizon. Shocks to economic growth reduce inflation in the third month to a significant degree.

\subsection{Variance Decomposition Analysis}

In examining the role of external and domestic factors in economic fluctuations in Pakistan, we perform a variance decomposition analysis that measures the percentage of the forecast error variances at different forecast horizons that are attributable to individual shocks or a group of shocks. These are presented in Table 3. The 1, 6 12, 18 and 24-month decomposition of forecast error variance is presented for the domestic variables. Oil prices and exchange rates are the important contributors to errors associated with the real interest rate. Almost 7 percent of the forecast error variances is shared by oil prices, while 14 percent is shared by the exchange rate. Inflation is shared primarily by the real interest rate and oil prices. Economic growth is shared by US demand and the exchange rate. 
Table 3: Variance decomposition results

\begin{tabular}{|c|c|c|c|c|c|c|}
\hline Month & Oil prices & US growth & $\begin{array}{c}\text { Real } \\
\text { interest } \\
\text { rate }\end{array}$ & $\begin{array}{c}\text { Real } \\
\text { exchange } \\
\text { rate }\end{array}$ & $\begin{array}{c}\text { Domestic } \\
\text { economic } \\
\text { growth }\end{array}$ & $\begin{array}{c}\text { Consumer } \\
\text { price } \\
\text { inflation }\end{array}$ \\
\hline \multicolumn{7}{|c|}{ Variance decomposition of real interest rate } \\
\hline 1 & 0.37 & 1.57 & 98.06 & 0.00 & 0.00 & 0.00 \\
\hline 6 & 1.69 & 0.41 & 90.63 & 6.62 & 0.07 & 0.58 \\
\hline 12 & 6.34 & 1.67 & 79.63 & 11.56 & 0.09 & 0.72 \\
\hline 18 & 7.36 & 2.57 & 75.26 & 13.72 & 0.13 & 0.95 \\
\hline 24 & 7.43 & 2.95 & 74.12 & 14.23 & 0.13 & 1.15 \\
\hline \multicolumn{7}{|c|}{ Variance decomposition of real exchange rate } \\
\hline 1 & 0.00 & 0.66 & 0.87 & 98.48 & 0.00 & 0.00 \\
\hline 6 & 2.11 & 2.42 & 1.68 & 90.06 & 1.27 & 2.45 \\
\hline 12 & 2.17 & 2.57 & 1.78 & 88.38 & 1.97 & 3.13 \\
\hline 18 & 2.19 & 2.60 & 1.84 & 88.14 & 2.00 & 3.23 \\
\hline 24 & 2.20 & 2.61 & 1.87 & 88.08 & 2.00 & 3.24 \\
\hline \multicolumn{7}{|c|}{ Variance decomposition of domestic economic growth } \\
\hline 1 & 0.36 & 0.65 & 0.40 & 0.23 & 98.37 & 0.00 \\
\hline 6 & 2.67 & 4.79 & 0.71 & 3.14 & 86.78 & 1.90 \\
\hline 12 & 2.88 & 5.06 & 0.92 & 3.52 & 84.97 & 2.65 \\
\hline 18 & 2.93 & 5.13 & 0.93 & 3.55 & 84.77 & 2.69 \\
\hline 24 & 2.94 & 5.13 & 0.94 & 3.55 & 84.75 & 2.69 \\
\hline \multicolumn{7}{|c|}{ Variance decomposition of consumer price inflation } \\
\hline 1 & 0.66 & 1.49 & 44.90 & 3.72 & 0.13 & 49.10 \\
\hline 6 & 5.47 & 4.01 & 38.12 & 4.40 & 2.45 & 45.56 \\
\hline 12 & 6.16 & 5.35 & 36.91 & 4.95 & 2.94 & 43.68 \\
\hline 18 & 6.28 & 5.34 & 37.34 & 5.34 & 2.94 & 42.76 \\
\hline 24 & 6.37 & 5.28 & 37.60 & 5.68 & 2.91 & 42.18 \\
\hline
\end{tabular}

Note: Percentage of the k-step-ahead forecast error variance explained by.

\section{Conclusions and Policy Implications}

Since the early 1980s, central banks have improved their credibility in managing inflation expectations and controlling inflation, and thus been given greater autonomy by their governments. However, the onset of the global financial crisis called these institutional arrangements into question. The literature and stylized facts indicate that the recession in the aftermath of the crisis raised questions as to the effectiveness of monetary policy in advanced economies, where central banks were constrained by zero-bound or low interest rates. Monetary policy was, therefore, deemed less effective in a recession. Unconventional monetary policy and macro-prudential regulation were considered better ways of reviving the economy. 
Given the degree of global interconnectedness, an economic change in one part of the world can have spillover effects elsewhere. The global financial crisis, for instance, was triggered by a crisis in the US subprime mortgage market. Similarly, the loss in effectiveness of monetary policy resulted in historically low interest rates, with positive and negative effects for the rest of the world.

This paper investigates the effectiveness of monetary policy in Pakistan in the presence of external uncertainties stemming from changes in the economic growth of developed economies and international oil price movements. Decreasing returns in advanced economies are associated with capital flows to emerging economies - a benefit of expansionary monetary policies in the former. However, Pakistan has attracted lower capital inflows, primarily due to noneconomic factors. To gauge the impact of such international developments on Pakistan, we estimate an SVAR that measures the effect of international oil prices and global demand on a key macroeconomic variable. The SVAR is identified by imposing theoretical and statistical restrictions. We also test for robustness and structural shifts in the estimation procedure.

The real policy rate experiences an upward adjustment, the real exchange rate depreciates, economic growth slows down and inflation rises due to an unanticipated increase in international oil prices. We also find that, when the real policy rate increases, the real exchange rate appreciates, while economic growth and inflation rise due to an increase in US economic growth. The real policy rate adjusts upward in response to inflation and real exchange rate shocks. The real exchange rate depreciates if inflation increases. This indicates that monetary policy is an effective means of stabilizing consumer prices and currency values in Pakistan.

While independent central banks aim to control inflation and reduce inflation uncertainty, real economic growth and investor confidence are spillovers of the latter. It is well established that monetary policy cannot directly boost economic growth in the long run. Rather, it helps smooth out short-run fluctuations. Our empirical analysis suggests that this also holds for Pakistan. Enhancing real economic growth is the domain of fiscal policy. Therefore, the fiscal authority needs to help revive the economy in times of recession. Furthermore, the fiscal and monetary authorities must coordinate their policy efforts to improve the country's economic potential and manage inflation expectations. 


\section{References}

Ahmed, S. (2003). Sources of economic fluctuations in Latin America and implications for choice of exchange rate regimes. Journal of Development Economics, 72, 181-202.

Ahmed, S., Ara, I., \& Hyder, K. (2006). How external shocks and exchange rate depreciations affect Pakistan? Implications for choice of an exchange rate regime. SBP Research Bulletin, 2(1), 61-68.

Aizenman, J., Binici, M., \& Hutchison, M. M. (2014). The transmission of Federal Reserve tapering news to emerging financial markets (Working Paper No. 19980). Cambridge, MA: National Bureau of Economic Research.

Barro, R. J., \& Gordon, D. B. (1983). Rules, discretion and reputation in a model of monetary policy. Journal of Monetary Economics, 12(1), 101-121.

Beechey, M. J., Johannsen, B. K., \& Levin, A. T. (2011). Are long-run inflation expectations anchored more firmly in the Euro area than in the United States? American Economic Journal: Macroeconomics, 3(2), 104-129.

Bernanke, B. S. (2007, July). Inflation expectations and inflation forecasting. Address at the Monetary Economics Workshop of the National Bureau of Economic Research Summer Institute, Cambridge, MA.

Blanchard, O., Dell'Ariccia, G., \& Mauro, P. (2010). Rethinking macroeconomic policy. Journal of Money, Credit and Banking, 42(1), 199-215.

Bowman, D., Londono, J. M., \& Sapriza, H. (2015). US unconventional monetary policy and transmission to emerging market economies. Journal of International Money and Finance, 55, 27-59.

Calvo, G. A. (1978). On the time consistency of optimal policy in a monetary economy. Econometrica, 46(6), 1411-1428.

Fratzscher, M., Lo Duca, M., \& Straub, R. (2017). On the international spillovers of US quantitative easing. The Economic Journal. 10.1111/ecoj.12435

Georgiadis, G. (2016). Determinants of global spillovers from US monetary policy. Journal of International Money and Finance, 67, 41-61. 
Ishi, K., Stone, M., \& Yehoue, E. B. (2009). Unconventional central bank measures for emerging economies (Working Paper No. 09/226). Washington, DC: International Monetary Fund.

Jordà, O. (2005). Estimation and inference of impulse responses by local projections. American Economic Review, 95(1), 161-182.

Kydland, F. E., \& Prescott, E. C. (1977). Rules rather than discretion: The inconsistency of optimal plans. Journal of Political Economy, 85(3), 473-491.

Lin, J.-L., \& Tsay, R. S. (1996). Co-integration constraint and forecasting: An empirical examination. Journal of Applied Econometrics, 11(5), 519-538.

Philips, P. (1998). Impulse response and forecast error variance asymptotics in nonstationary VARs. Journal of Econometrics, 83(1-2), 21-56.

Rogoff, K. (1985). The optimal degree of commitment to an intermediate monetary target. Quarterly Journal of Economics, 100(4), 1169-1189.

Romer, P. (in press). The trouble with macroeconomics. American Economist.

Romer, C., \& Romer, D. (1989). Does monetary policy matter? A new test in the spirit of Friedman and Schwartz. NBER Macroeconomics Annual, 4, 121-184.

Rusticelli, E., Turner, D., \& Cavalleri, M. C. (2015). Incorporating anchored inflation expectations in the Phillips curve and in the derivation of OECD measures of equilibrium unemployment (Working Paper No. 1231). Paris: OECD.

Sims, C. A., Stock, J. H., \& Watson, M. W. (1990). Inference in linear time series models with some unit roots. Econometrica, 58(1), 113-144.

Tenreyro, S., \& Thwaites, G. (2016). Pushing on a string: US monetary policy is less powerful in recessions. American Economic Journal: Macroeconomics, 8(4), 43-74.

Weise, C. L. (1999). The asymmetric effects of monetary policy: A nonlinear vector autoregression approach. Journal of Money, Credit and Banking, 31(1), 85-108. 
Figure A1: Response of real policy rate

Oil price shock

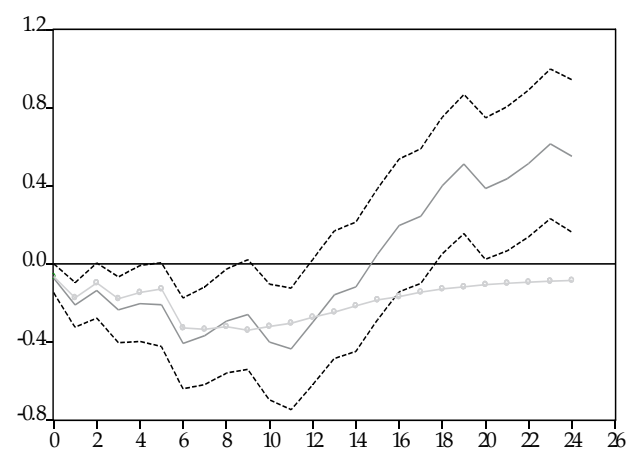

Real exchange rate shock

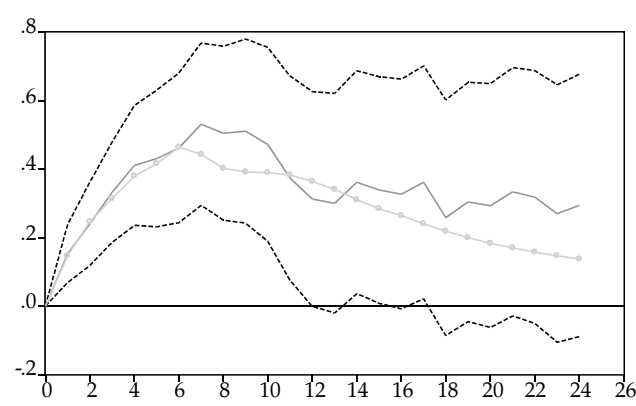

Domestic growth shock

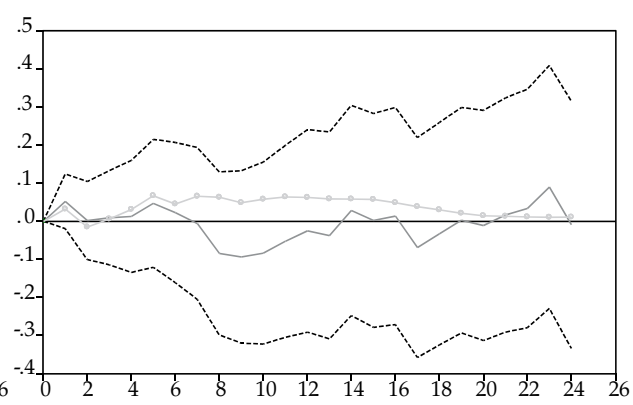

Consumer price inflation shock

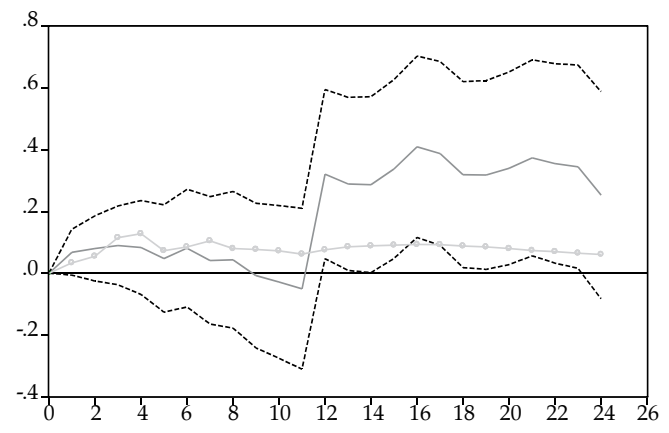




\section{Figure A2: Response of real exchange rate}

Oil price shock

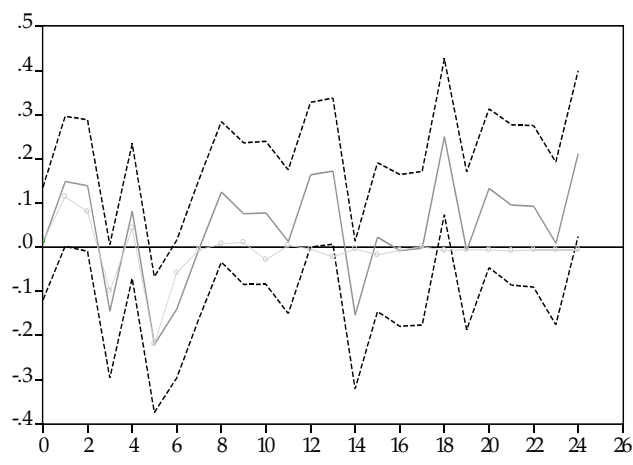

US growth shock

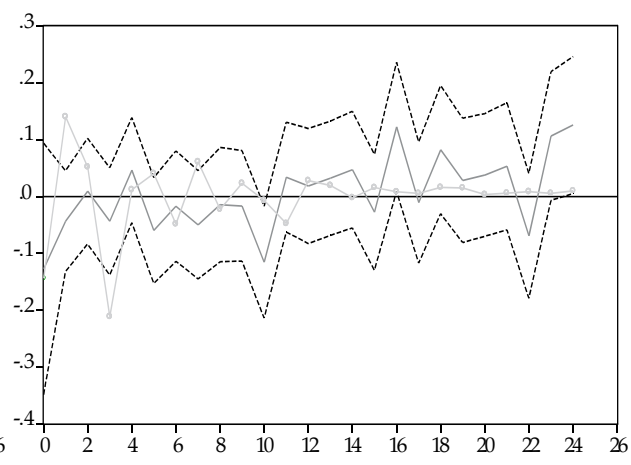

Domestic growth shock

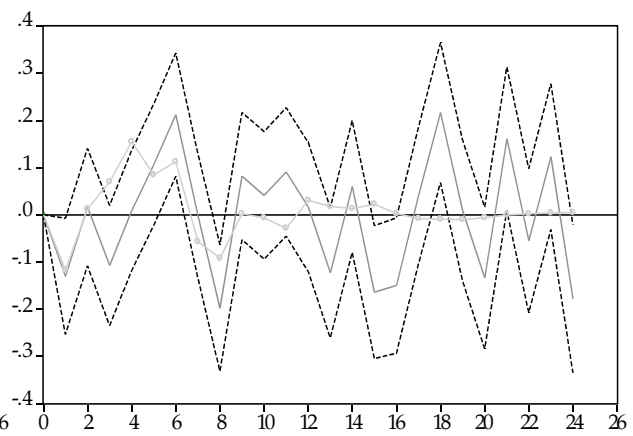

Consumer price inflation shock

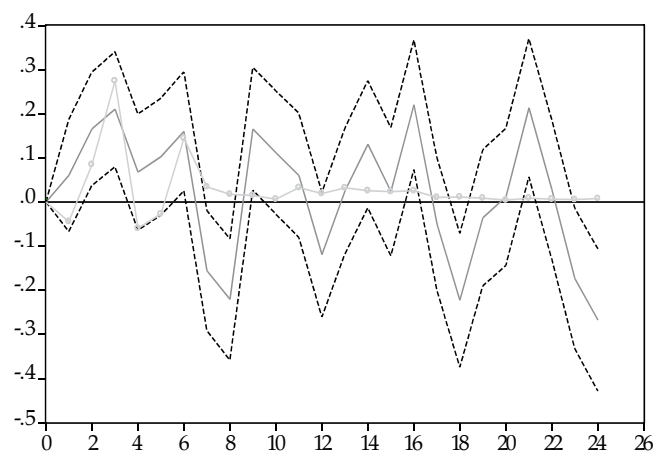


Figure A3: Response of domestic economic growth

Oil price shock

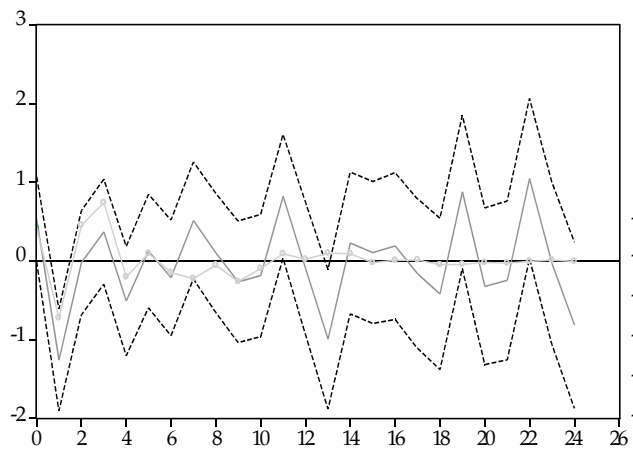

Real policy rate shock

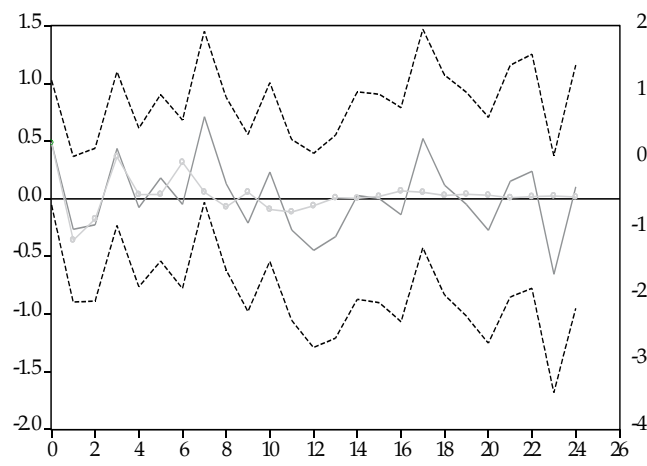

US growth shock

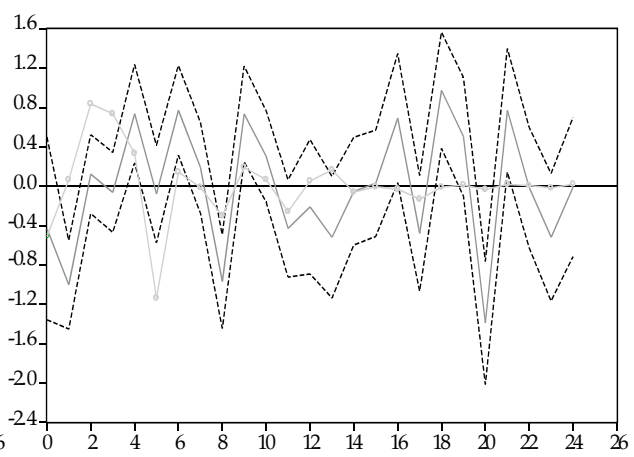

Real exchange rate shock

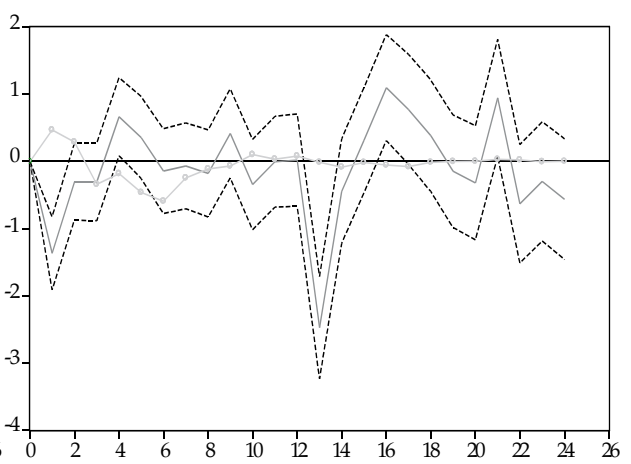

Consumer price inflation shock

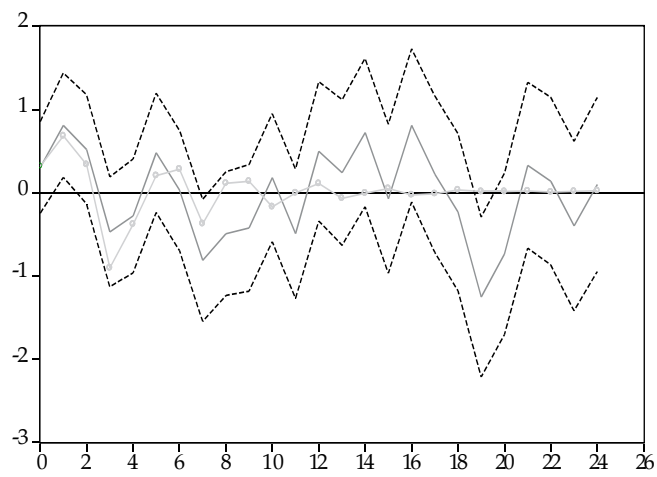


Figure A4: Response of consumer price inflation

Oil price shock

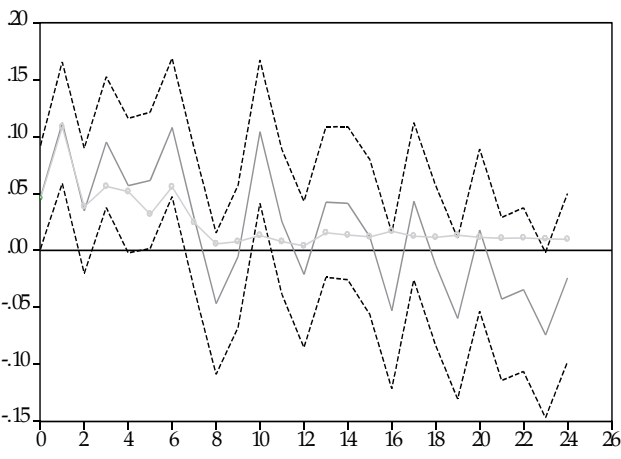

Real policy rate shock

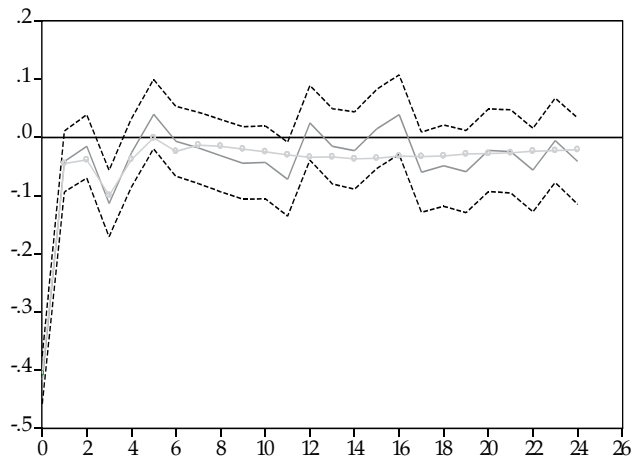

US growth shock

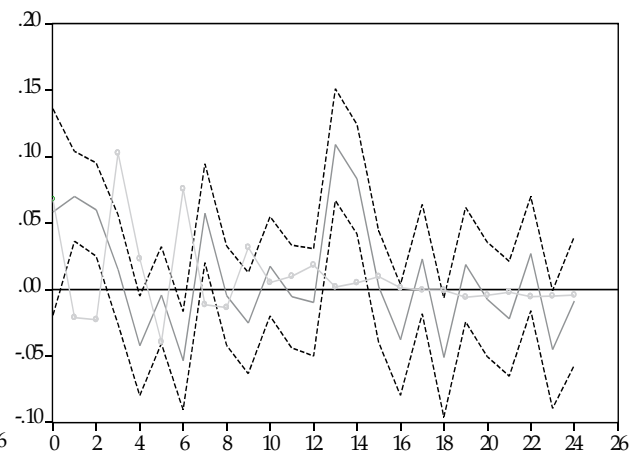

Real exchange rate shock

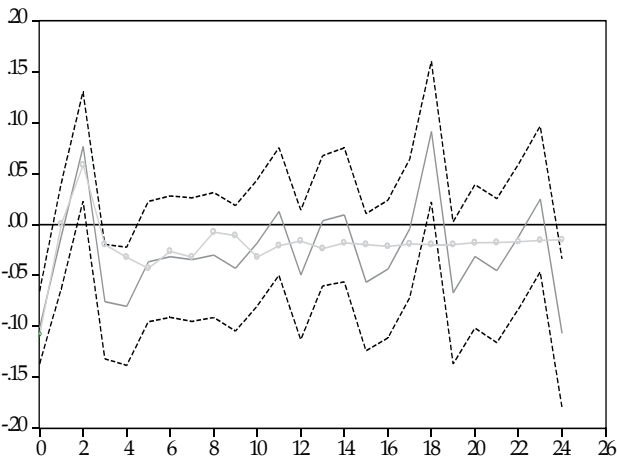

Domestic growth shock

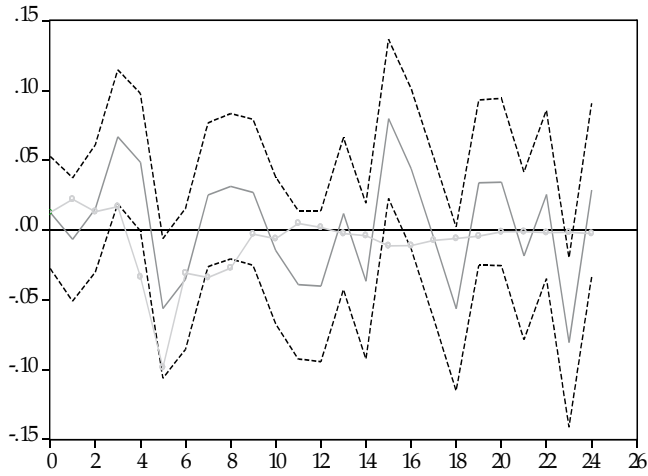




\section{Figure A5: Residuals of SVAR equations}

Oil prices

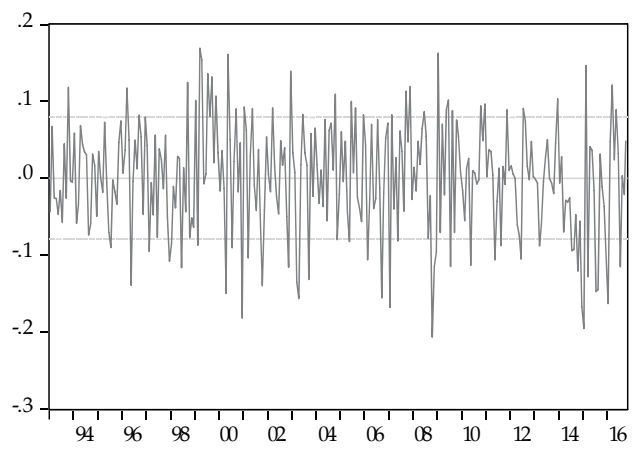

Real interest rates

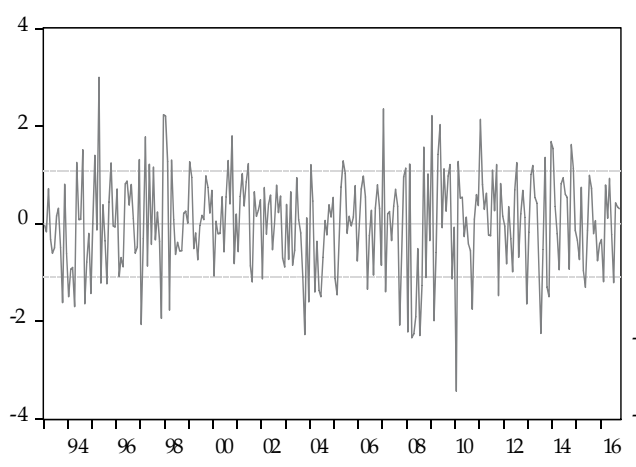

Industrial production (domestic)

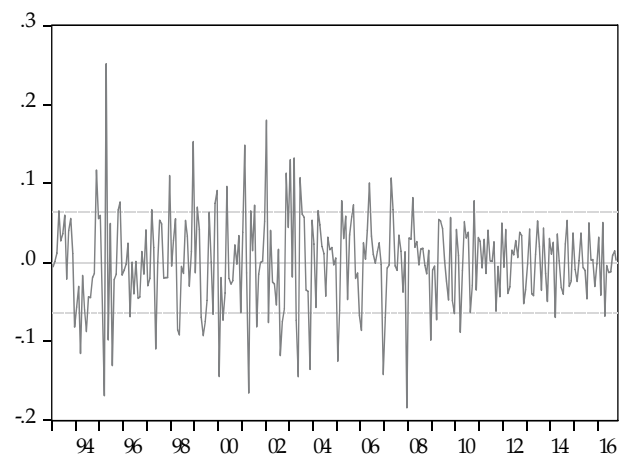

Industrial production (US)

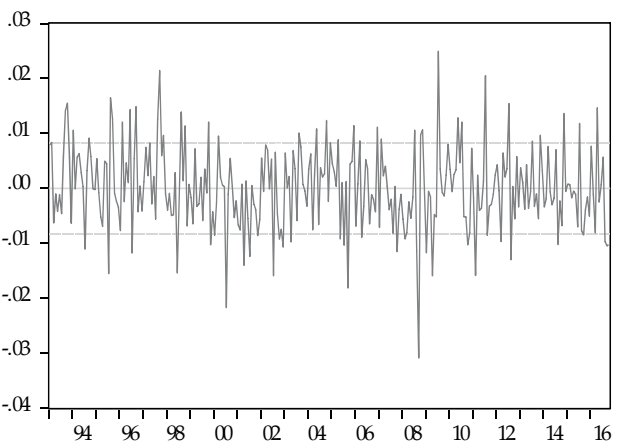

Real exchange rate

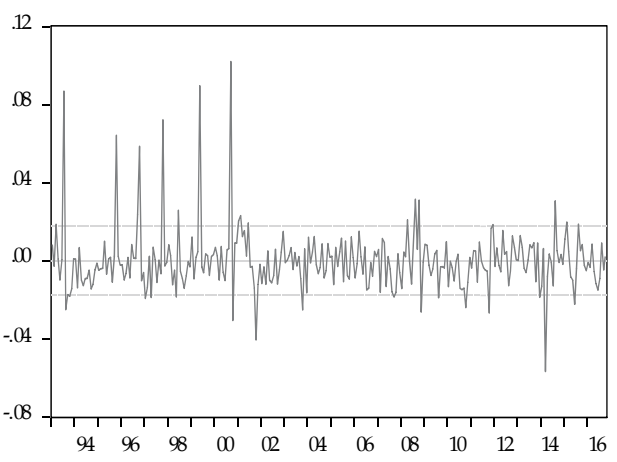

CPI inflation

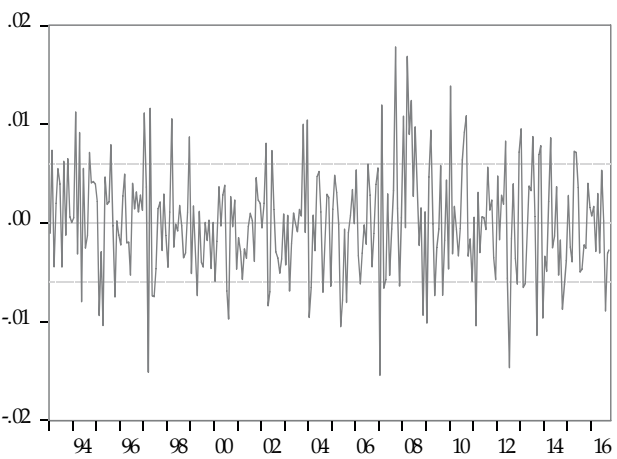

